\title{
Portunid crab predation on juvenile hard clams: effects of substrate type and prey density
}

\author{
Su Sponaugle, Peter Lawton* \\ Marine Sciences Research Center, State University of New York, Stony Brook, New York 11794-5000, USA
}

\begin{abstract}
Studies on predation are often based solely on the measurement of predator consumption rates, providing little information on underlying behavioral mechanisms. In this study, behavioral observations were used in conjunction with consumption rate analyses to investigate the predatory interactions between 2 brachyuran crabs, Ovalipes ocellatus and Callinectes sapidus, and juvenile hard clams Mercenaria mercenaria (15 to $20 \mathrm{~mm} \mathrm{SL}$ ). In laboratory experiments, O. ocellatus was observed foraging on 5 densities of clams $\left(24\right.$ to $120 \mathrm{~m}^{-2}$ ) in sand with and without the addition of natural shell debris. Across all prey densities, crab consumption rates were significantly higher in sand than in the sand/shell substrate. Behavioral observations indicated that crabs foraged less efficiently in sand/shell, particularly at low prey densities, suggesting the existence of a low-density prey refuge in the more heterogeneous substrate. In comparative experiments, where O. ocellatus and C sapidus were permitted to feed on a single low prey density $\left(24 \mathrm{~m}^{-2}\right)$ in 3 substrates (sand, sand/shell, sand/gravel), both crabs foraged most successfully in sand. Although consumption rates for both species were similar, behavioral observations demonstrate distinct differences in general crab behavior patterns. Direct behavioral observation of predatory interactions can provide critical information often unavailable through the measurement of consumption rates alone. Results suggest that utilization of low density prey refuges in heterogeneous substrates may be an effective strategy for reducing portunid crab predation on juvenile hard clams in mariculture operations
\end{abstract}

\section{INTRODUCTION}

Predation can be a significant factor defining community trophic structure, regulating species abundance and diversity, and thereby contributing to population stability (e.g. Paine 1980, Dayton 1984, Sih et al. 1985). One approach to the study of predation is that of experimental component analysis (Holling 1959, 1965), which partitions complex predatory interactions into simple components, such as attack rate, handling time, and predator-prey exposure time. Experimental manipulations can then provide estimates for the components, resulting in the synthesis of a mathematical model describing the predator-prey interaction (Holling 1959, 1965, Krebs 1973).

A predator's functional response, the relationship between feeding rate and prey density (Solomon 1949, Holling 1959, 1965), is often used to describe the predation interaction. Predators appear to conform to one of

\footnotetext{
- Present address: Department of Fisheries and Oceans, Biological Station, St. Andrews, New Brunswick, Canada EOG $2 \times 0$
}

3 primary functional response relationships (Holling 1959, 1965, Real 1977). Type I responses are exhibited by predators, such as filter feeders, whose consumption of prey increases linearly until an abrupt satiation plateau. Increase in prey consumption rates for Type II predators, however, decelerates with increasing prey density to an upper asymptote. The sigmoid Type III response, often demonstrated by predators exhibiting more complex behaviors, reflects an initial acceleration before a decelerating rise to an upper asymptote. The form of the functional response can vary with different environmental conditions for a particular predator-prey interaction (Murdoch \& Oaten 1975, Hassel 1978, Real 1979, Abrams 1982, Lipcius \& Hines 1986, Eggleston 1990).

In previous studies, foraging parameters (handling time, search time, etc.) have been derived from calculations based on functional response equations, and extended to predict underlying behavioral mechanisms. The initial acceleration of Type III responses, for example, has been variously attributed to learning (Holling 1965, Murdoch 1973), increased predator efficiency and/or an increase in the proportion of time 
spent foraging (Hassel et al. 1977, Hassel 1978), and increased velocity of prey search (Dunbrack \& Giguere 1987) with higher prey densities. Valiela (1984) and Greene et al. (1986) have argued, however, that this procedure can lead to erroneous conclusions since the calculation of parameters based on theoretically derived curves can be unreliable. Determination of behavioral mechanisms underlying functional responses should therefore rely on direct measurement of behavioral parameters.

This study utilizes both behavioral observations and functional response analyses to investigate the predatory relationship between large portunid crabs and juvenile hard clams Mercenaria mercenaria (L.). Understanding the population dynamics of marine bivalves has become increasingly important with the recent decline (Buckner 1983, McHugh 1983) in natural bivalve populations along the Atlantic coast of the United States. In response to this decline, major artificial field enhancement ('re-seeding') programs have been developed by both private industry and public (town) organizations of coastal states. Re-seeding operations have met with only limited success, however, due to extensive predation on juvenile clams (Menzel et al. 1976, Castagna \& Kraeuter 1977. Whetstone \& Eversole 1978, Flagg \& Malouf 1983). On Long Island, NY (USA), juvenile M. mercenaria (15 to $20 \mathrm{~mm}$ in shell length, SL) are readily consumed by large portunid crabs such as Ovalipes ocellatus (Herbst) and Callinectes sapidus Rathbun (pers. obs.). Studying this predatory interaction under several environmental conditions may also provide information useful in developing techniques to biologically control the predation of juvenile clams by large crustaceans.

Recent studies of predation have suggested that bivalves can obtain a refuge from several marine predators in particular substrates (Arnold 1984, Lipcius \& Hines 1986), habitats (Blundon \& Kennedy 1982, Peterson 1982a) and densities (Malinowski \& Whitlatch 1983, Boulding \& Hay 1984, Lipcius \& Hines 1986). Refugia traditionally have been distinguished by analysis of the predator's feeding success and/or functional response. Demonstration of a Type III functional response, for example, could reflect the existence of a density-dependent refuge, though the behavior mechanisms underlying the response are often unclear. To determine the possible existence of prey refugia, as well as the underlying behavioral components, the present study utilized laboratory observations on the lady crab Ovalipes ocellatus foraging on clams planted at several densities in several substrates. A second experiment compared the foraging behavior of $O$. ocellatus with that of the blue crab Callinectes sapidus to test the generality of the results obtained for O. ocellatus.

\section{MATERIALS AND METHODS}

General experimental conditions. Juvenile Mercenaria mercenaria $(15$ to $20 \mathrm{~mm}$ shell length, SL; 1987 production) were obtained from F. M. Flower and Sons Shellfish Hatchery, Bayville, NY (USA), and maintained in a flow-through aquarium supplied with unfiltered seawater for no longer than $3 \mathrm{wk}$ prior to use in trials. Male Ovalipes ocellatus $(65$ to $80 \mathrm{~mm}$ carapace width. CW) were captured by hand in shallow waters off Long Island, NY, while recently-caught male Callinectes sapidus $(100$ to $130 \mathrm{~mm} \mathrm{CW}$, including lateral spines) were obtained from local fishmarkets. Both species were selected for inclusion in the trials using the same criteria. Although the blue crabs were larger, clam consumption rates for both species proved to be similar.

An azoic sand substrate was prepared by sieving beach sand through a $0.1 \mathrm{~mm}$ mesh, then washing it thoroughly to remove fine particulates. The resulting coarse sand was representative of field conditions. The sand/shell substrate used in both experiments consisted of natural shell fragments - primarily Crepidula formicata Say, Mercenaria mercenaria, and Mytilus edulis (L.) - and gravel debris suspended in sand. The shell and gravel debris was collected by sieving ( $4.0 \mathrm{~mm}$ mesh) material from a commercial clam bed. Debris consisting of a $2: 2: 1$ ratio of shell, small gravel ( $\leq 10 \mathrm{~mm}$ diameter) and large gravel (>10 $\mathrm{mm}$ diameter) by volume was sorted to remove live material, then washed and oven dried. This preparation was then combined with azoic sand in a 1:4 ratio to form a sand/ shell substrate comparable to that in field samples. A third substrate, sand/gravel, was used only in Experiment II, and consisted of commercially obtained gravel ( $\leq 17 \mathrm{~mm}$ in diameter) combined with azoic sand to form a mixture of ca $30 \%$ gravel by volume.

Plexiglass aquaria $\left(0.5 \mathrm{~m}^{2}\right.$ base area) were filled to a depth of $70 \mathrm{~mm}$ with one of the 3 substrates, and supplied with recirculating seawater. Salinity was maintained between 28 and $33 \%$, and water temperature ranged between 22 and $25^{\circ} \mathrm{C}$ during the course of the study (June to October 1987). Natural diel cycles were simulated in the laboratory using fluorescent lights controlled by a custom-built dimming unit (Day \& Lawton 1989). Light intensity was modulated over $75 \mathrm{~min}$ periods to simulate daily crepuscular periods. A microprocessor-based timing unit enabled daily adjustment of the onset of each crepuscular period to approximate the daily progression of sunrise and sunset (Day \& Lawton 1989). During night observations, illumination was provided by adjustable safelight lamps which emitted light of wavelengths greater than $600 \mathrm{~nm}$. Cronin (1986) has shown previously that brachyuran crabs are insensitive to light at these longer wavelengths. 
Experiment I: Tests of predatory responses by Ovalipes ocellatus. Individual male Ovalipes ocellatus were allowed to feed on juvenile Mercenaria mercenaria planted at 5 densities $\left(24,48,72,96,120 \mathrm{~m}^{-2}\right)$ in the sand and sand/shell substrates. These densities were within the range of planting densities achieved in local mariculture operations (Lawton unpubl. data). Controls lacking predatory crabs were run for both the lowest and highest densities. Both treatments and controls were replicated 5 times, with random spatial and temporal assignment to aquaria.

Prior to use in the trials, crabs were fed ad libitum on a diet of 30 clams over $48 \mathrm{~h}$. Those crabs which fed on a minimum of 15 clams were then starved for an additional $72 \mathrm{~h}$, and introduced into the experimental tanks. Each crab was used in only 1 trial. To initiate a predation trial, clams were distributed by hand over the substrate surface and then inserted until the upper shell margin was ca $28 \mathrm{~mm}$ below the surface, the depth to which clams bury naturally over several hours (own obs.). Crabs were introduced to each aquarium at 12:00 noon on the first day of each $48 \mathrm{~h}$ trial.

Behavioral observations were made, using timelapse video techniques, for 3 of the 5 replicates in each prey density/substrate combination. Videotaping was initiated $60 \mathrm{~min}$ prior to the onset of the first crepuscular periods in each trial and continued for $6 \mathrm{~h}$ thereafter. This period was selected to encompass the period of most active crab foraging, determined from preliminary trials where 5 crabs foraging in sand on a low density of clams $\left(24 \mathrm{~m}^{-2}\right)$ were monitored continuously for $24 \mathrm{~h}$ (Fig. 1).

Consumption rates were measured after $24 \mathrm{~h}$ and

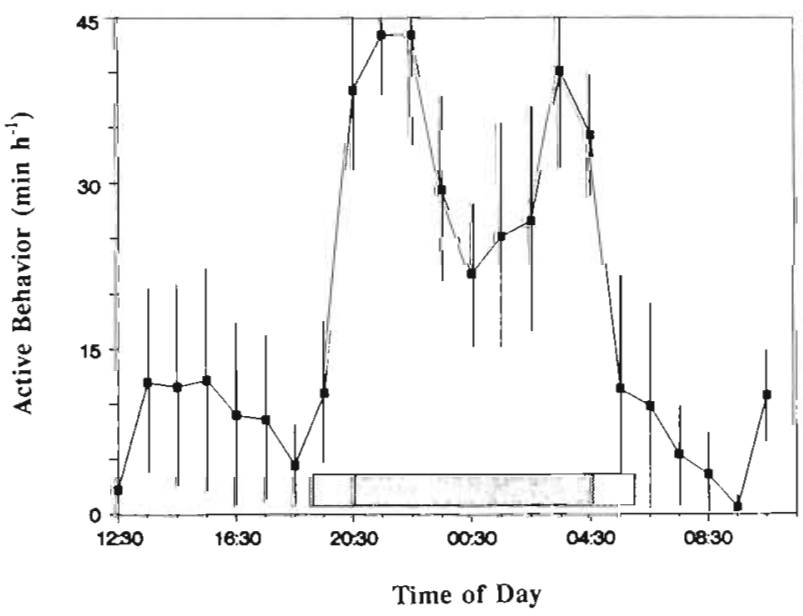

Fig. 1. Ovalipes ocellatus. Mean time $\left( \pm 1 \mathrm{SE}_{i} \mathrm{n}=5\right)$ in which crabs were engaged in active behavior during each hour of a $24 \mathrm{~h}$ period. Crabs were continuously monitored using timelapse video techniques. Darkly-stippled area is representative of night period; lighter-stippled regions indicate $75 \mathrm{~min} \mathrm{cre}$ puscular periods at dawn and dusk again after $48 \mathrm{~h}$ by sieving the substrate surface (top $10 \mathrm{~mm}$ ) for clams shell hinges on the second day of the trial, and the entire tank for hinges and live clams on the third day Retrieval of shell fragments by gently sieving the surface sediment the morning of the second day minimized any impact on crab foraging behavior since at that time crabs were invariably buried below the substrate surface. If few or no clams were consumed by the end of a trial, crabs were tested to demonstrate feeding abilities. Trials were rejected if crabs did not feed adequately ( 5 or more clams out of 10 , over $12 \mathrm{~h}$ ) during this test. Rejected trials were subsequently repeated with a new crab.

Experiment II: Tests comparing predatory responses by Ovalipes ocellatus and Callinectes sopidus. To compare the feeding responses of Ovalipes ocellatus and Callinectes sapidus, both crabs were presented with clams planted at a single low density (24 clams $\mathrm{m}^{-2}$ ) in 3 substrates (sand, sand/shell, sand/gravel). The sand/gravel substrate was used because gravel has previously been suggested as an appropriate substrate in which to plant clams at risk to crab predation (Menzel et al. 1976, Castagna \& Kraeuter 1977, Kraeuter \& Castagna 1980). Additionally, in previous laboratory trials clams have been found to be more vulnerable to $C$. sapidus predation in sand, mud and a sand/mud mixture than in crushed oyster or granite gravel (Arnold 1984).

Methods used to pretreat crabs, record crab behavior and measure predation rates were identical to procedures used in Expt I, with the exception that all 4 replicates of each treatment were videotaped.

Statistical analysis. Consumption of clams: In both experiments, consumption rates, i.e. the numbers of clams consumed per treatment, were analyzed by 2 way ANOVA (Wilkinson 1987). Bartlett's test for homogeneity of variances (Zar 1984) was applied to each data set prior to ANOVA. Although the data proved to be heteroscedastic, ANOVA is sufficiently robust to accommodate heteroscedasity if the sample sizes are equal (Zar 1984). Where interaction effects were significant, Ryan's $Q$ multiple comparison test (RQT) set at an experiment wise error rate (EER) of 0.05 (Einot \& Gabriel 1975, Day \& Quinn 1989) was used to compare the means.

To distinguish functional response curves in Expt I proportional mortalities, i.e. the proportion of available clams consumed, were angular (arc-sine square-root) transformed to meet assumptions of normality and homogeneity of variances and analyzed with ANOVA (Lipcius \& Hines 1986, Eggleston 1990). One-way ANOVAs were applied to reveal substrate-specific patterns in functional response. Functional response type can be distinguished by the slope of proportional mortalities relative to prey density. A positive slope indi- 
cates positive density-dependent predation (a Type III functional response), a negative slope, a Type II, inversely density-dependent functional response, and no slope, a Type I response (Hassel 1978, Trexler et al. 1988, Eggleston 1990). A significant influence of density on proportional mortality would therefore indicate either a Type II or Type III functional response, while a lack of density dependence could reflect a Type I functional response (Eggleston 1990). To distinguish a Type II functional response from a Type III response, Ryan's Q multiple comparison test (RQT:EER $=0.05$ ) (Einot \& Gabriel 1975, Day \& Quinn 1989) was applied to mean proportional mortalities. Significantly greater proportional mortalities at low prey densities would indicate a Type II functional response, while significantly lower proportional mortalities at low prey densities would demonstrate a Type III functional response (Eggleston 1990).

Crab behavior: Crab behavior was classified into specific activities and general behavioral categories for statistical analysis (Table 1). The amount of time individual crabs spent in specific activities was recorded continuously from the videotape records and expressed as the total and proportional time (i.e. of the $6 \mathrm{~h}$ observation period) spent in each activity or behavioral category. Handling times (time crabs spent handling prey, see Table 1) could be measured from the videotape records, as well as encounter times, defined as the time crabs spent actively foraging (including inter- mittent search and searching activities) between prey encounters.

The proportion of total time crabs spent in each general behavioral category were compared for both experiments. Proportions were angularly (arc-sine square-root) transformed to meet assumptions of normality and homogeneity of variances, and analyzed by 2 -way ANOVA. The proportion of time spent in specific foraging activities (i.e. searching, intermittent search, handling prey and handling non-prey) was also analyzed using ANOVA. Handling and encounter times were inverse square-root transformed to meet assumptions of normality and homogeneity of variances, and analyzed by 2-way ANOVA.

\section{RESULTS}

\section{Experiment I: Tests of predatory responses by Ovalipes ocellatus}

Consumption of clams

Substrate type and clams density significantly influenced consumption rates for Ovalipes ocellatus feeding on juvenile Mercenaria mercenaria over $48 \mathrm{~h}$, with no significant interaction (Fig. 2, Table 2I). Foraging in the sand/shell substrate was significantly more variable than in sand (Bartlett's test for homogeneity of variance: $F=2.64$, df $=9, p<0.005$ ). Only one of the 360 clams used in the control trials died during the

Table 1. Ovalipes ocellatus and Callinectes sapidus. Classification of crab behavior into specific activities and general behavior categories

\begin{tabular}{|c|c|c|c|}
\hline $\begin{array}{l}\text { General behaviour } \\
\text { category }\end{array}$ & & Specific activity & Activity definition \\
\hline (1) Burial & & Burial & $50 \%$ of dorsal carapace under substrate surface \\
\hline \multirow[t]{5}{*}{ (2) Non foraging } & A & Inactivity & $\begin{array}{l}\text { Body above substrate surface, no movement of chelipeds or walking } \\
\text { legs }\end{array}$ \\
\hline & B & Grooming & Scraping or picking of body surfaces using chelipeds or walking legs \\
\hline & $\mathrm{C}$ & Walking & $\begin{array}{l}\text { Locomotion } \geq 1 \text { body length across substrate, walking legs penetrat- } \\
\text { ing only to dactyl-propodus joint }\end{array}$ \\
\hline & $\mathrm{D}$ & Aggression & $\begin{array}{l}\text { Chelipeds open and/or raised; carapace elevated off substrate } \\
\text { surface; swimming legs often moving; locomotion across substrate } \\
\text { possible }\end{array}$ \\
\hline & $E$ & Swimming & Movement through water column, using swimming legs \\
\hline \multirow[t]{4}{*}{ (3) Foraging } & A & Intermittent search & $\begin{array}{l}\text { Searching ( } 3 \mathrm{~B} \text { ) for } 30-50 \% \text { of the time period; walking }(2 \mathrm{C}) \text { for } \\
50-70 \% \text { of the time }\end{array}$ \\
\hline & B & Searching & $\begin{array}{l}\text { Crab either stationary or moving, using walking legs to probe sub- } \\
\text { strate, penetration to propodus-carpus joint }\end{array}$ \\
\hline & $\mathrm{C}$ & Handling of prey & $\begin{array}{l}\text { Contact with prey, including excavation from substrate, manipula- } \\
\text { tion with chelipeds and mandibles, shell crushing and flesh } \\
\text { consumption }\end{array}$ \\
\hline & $\mathrm{D}$ & Handling of non-prey & $\begin{array}{l}\text { Manipulation of shell and gravel pieces with chelipeds and } \\
\text { mandibles }\end{array}$ \\
\hline
\end{tabular}



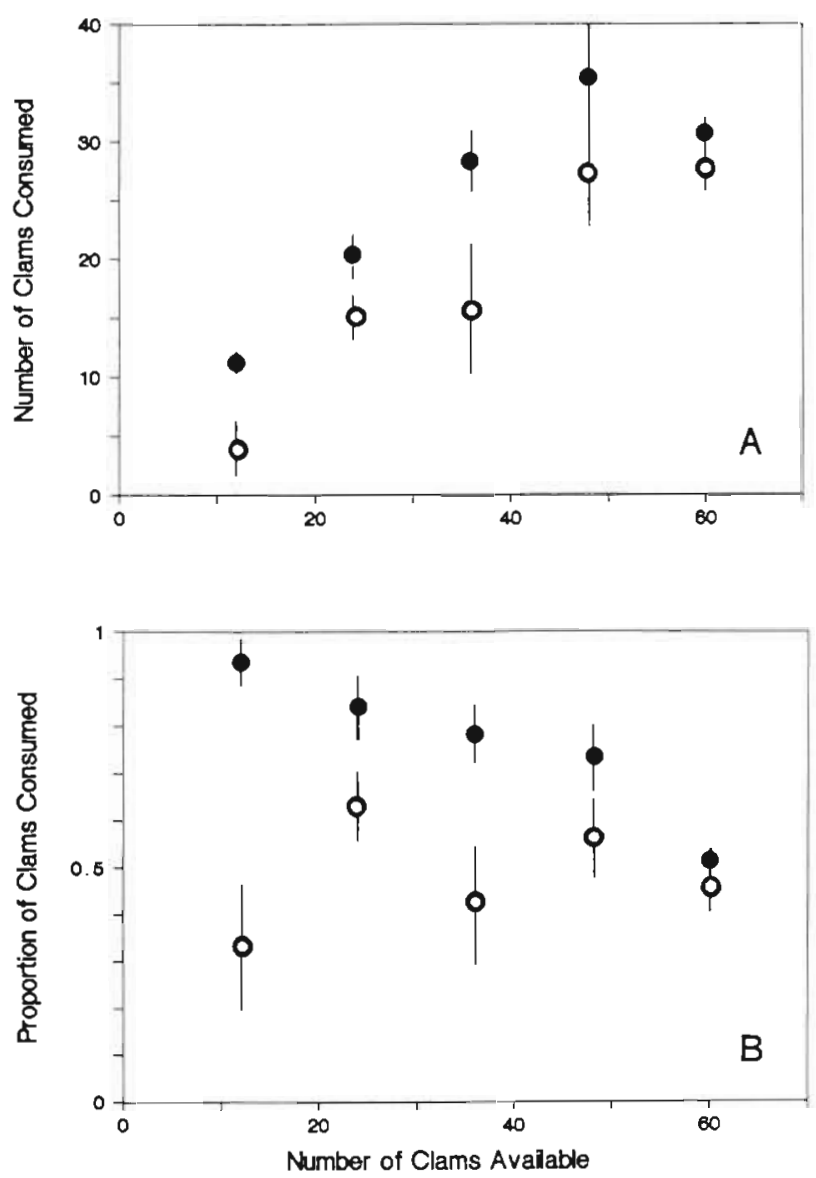

Fig. 2. Ovalipes ocellatus preying on juvenile Mercenaria mercenaria. Mean number ( $\left.\pm 1 \mathrm{SE}_{2} \mathrm{n}=5\right)(\mathrm{A})$ and mean proportion ( $\pm 1 \mathrm{SE} ; \mathrm{n}=5$ ) (B) of clams consumed at 5 prey densities in a sand (solid circles) and a sand/shell substrate (open circles)

trials, verifying that natural mortality was insignificant during the experiment.

One-way ANOVA on the transformed proportional mortalities indicated a significant influence of density in sand, but not in sand/shell (Table 2 I). Pairwise comparisons of the means in sand revealed that the mean proportional mortality at the lowest prey density was significantly greater than the other means (RQT:EER = 0.05), demonstrating that crabs exhibited a Type II response in sand. Because ANOVA was non-significant for the sand/shell substrate, however, the Type I functional response could not be eliminated. Although the specific functional response type could not be distinguished, it is suggested that substrate-related differences in foraging success exist, with crabs in the sand/ shell substrate exhibiting lower and more variable consumption rates in sand/shell.

Corroboration for substrate-specific foraging success is evident in the examination of the number of clams consumed during the second night (Fig. 3). Although
Table 2. Ovalipes ocellatus and Callinectes sapidus feeding on Mercenaria mercenaria. Statistics from ANOVA performed on Expt I and Expt II data. Consumption and proportional mortality data based on clam consumption after $48 \mathrm{~h}$; behavioral data based on $6 \mathrm{~h}$ videotape records. Refer to text for descriptions of specific analyses

\begin{tabular}{|c|c|c|c|c|}
\hline $\begin{array}{l}\text { Data used in } \\
\text { ANOVA }\end{array}$ & Factor & F & $\mathrm{d} f$ & $\mathrm{p}$ \\
\hline \multicolumn{5}{|l|}{ I } \\
\hline \multirow[t]{3}{*}{ Consumption rate } & Substrate & 13.4 & 1 & $<0.001$ \\
\hline & Density & 18.3 & 4 & $<0.001$ \\
\hline & Interaction & 0.7 & 4 & NS \\
\hline \multicolumn{5}{|c|}{$\begin{array}{l}\text { Proportional mortality } \\
\text { (One way) }\end{array}$} \\
\hline Sand & Density & 6.1 & 4 & 0.002 \\
\hline Sand /shell & Density & 1.1 & 4 & NS \\
\hline \multicolumn{5}{|c|}{$\begin{array}{l}\text { Proportion of time in } \\
\text { general behaviors: }\end{array}$} \\
\hline \multirow[t]{3}{*}{ Buried } & Substrate & 4.5 & 1 & 0.05 \\
\hline & Density & 2.0 & 4 & NS \\
\hline & Interaction & 0.6 & 4 & NS \\
\hline \multirow[t]{3}{*}{ Non-foraging } & Substrate & 0.5 & 1 & NS \\
\hline & Density & 2.7 & 4 & NS \\
\hline & Interaction & 2.8 & 4 & NS \\
\hline \multirow[t]{3}{*}{ Foraging } & Substrate & 2.9 & 1 & NS \\
\hline & Density & 0.7 & 4 & NS \\
\hline & Interaction & 1.0 & 4 & NS \\
\hline \multirow[t]{3}{*}{ Handling time } & Substrate & 0.2 & 1 & NS \\
\hline & Density & 0.9 & 4 & NS \\
\hline & Interaction & 0.2 & 4 & NS \\
\hline \multirow[t]{3}{*}{ Encounter time } & Substrate & 26.7 & 1 & $<0.001$ \\
\hline & Density & 3.6 & 4 & 0.007 \\
\hline & Interaction & 0.5 & 4 & NS \\
\hline \multicolumn{5}{|l|}{ II } \\
\hline \multirow[t]{3}{*}{ Consumption rate } & Substrate & 20.4 & 2 & $<0.001$ \\
\hline & Species & 0.02 & 1 & NS \\
\hline & Interaction & 5.5 & 2 & 0.01 \\
\hline \multicolumn{5}{|c|}{$\begin{array}{l}\text { Proportion of time in } \\
\text { general behaviors: }\end{array}$} \\
\hline \multirow[t]{3}{*}{ Buried } & Species & 15.3 & 1 & 0.001 \\
\hline & Substrate & 0.3 & 2 & NS \\
\hline & Interaction & 0.7 & 2 & NS \\
\hline \multirow[t]{3}{*}{ Non-foraging } & Species & 11.4 & 1 & 0.003 \\
\hline & Substrate & 0.7 & 2 & NS \\
\hline & Interaction & 0.04 & 2 & NS \\
\hline \multirow[t]{3}{*}{ Foraging } & Species & 0.4 & 1 & NS \\
\hline & Substrate & 0.2 & 2 & NS \\
\hline & Interaction & 2.5 & 2 & NS \\
\hline
\end{tabular}

this comparison was less standardized since individuals fed on different numbers of clams during the first night (as indicated in Fig. 3), it provided a wider spread in the number of prey available for consumption. In general, crabs demonstrated higher consumption rates in sand than in sand/shell at low prey densities. 


\section{Crab behavior}

Crabs demonstrated the full range of behaviors listed in Table 1. From videotape analyses of individual crab feeding sequences, crabs appeared to forage on clams throughout the tank. Although most walking occurred around the tank edges, foraging was not obviously confined to that area, suggesting that tank effects on experimental results were minimal.

Ovalipes ocellatus spent significantly more time buried in sand than in sand/shell, while differences in time spent in non-foraging behaviors were not significant (Table 2 I). Although differences in the proportion of time spent foraging were also not significant (Table 2 I), analysis of each specific foraging activity revealed substrate-related differences. A greater proportion of time was spent searching for prey in sand/ shell (ANOVA:F $=8.7, \mathrm{df}=1,20, \mathrm{p}=0.008$ ), while a smaller proportion of time was spent handling prey

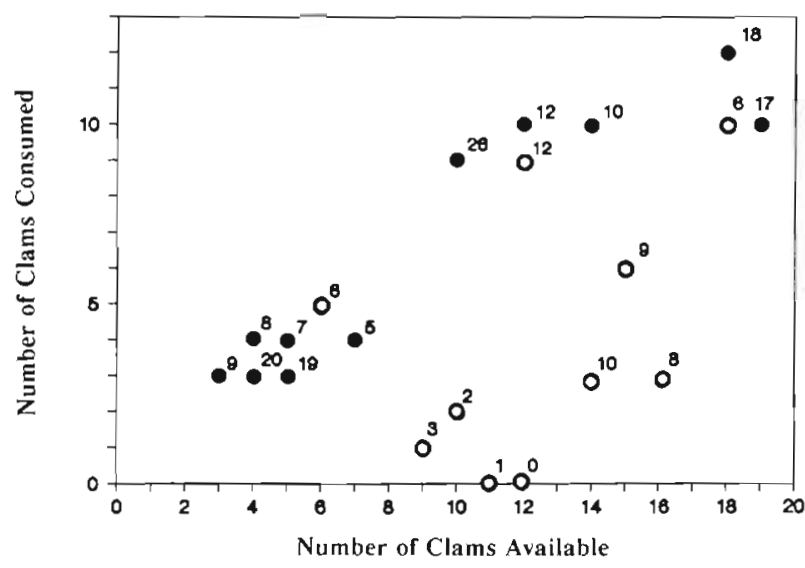

Fig. 3. Ovalipes ocellatus preying on juvenile Mercenaria mercenaria. Number of clams consumed during the second $24 \mathrm{~h}$ period of a $48 \mathrm{~h}$ trial in sand (solid circles) and sand/shell (open circles) for trials with 20 or fewer clams remaining after the first $24 \mathrm{~h}$. Number of clams consumed during the first $24 \mathrm{~h}$ is indicated beside each datum

Table 3. Ovalipes ocellatus. Mean time (min $\pm 1 \mathrm{SE}$ ) crabs were engaged in general and specific behaviors for Expt I. Data summed across all prey densities $(15 \times 16 \mathrm{~h}$ videotape records for each substrate) are depicted to illustrate general crab behavior patterns

\begin{tabular}{|c|c|c|c|c|}
\hline & \multicolumn{4}{|c|}{ General behavior } \\
\hline \multirow{4}{*}{$\begin{array}{l}\text { Sand } \\
\text { Sand/shell }\end{array}$} & $223.2 \pm 21.9$ & \multicolumn{2}{|c|}{$28.2 \pm 8.2$} & $73.8 \pm 15.5$ \\
\hline & $194.5 \pm 21.3$ & & & $110.6 \pm 12.8$ \\
\hline & \multicolumn{4}{|c|}{ Foraging behavior only } \\
\hline & $\begin{array}{l}\text { Intermittent } \\
\text { search }\end{array}$ & Searching & $\begin{array}{c}\text { Handling } \\
\text { of prey }\end{array}$ & $\begin{array}{c}\text { Handling of } \\
\text { non-prey }\end{array}$ \\
\hline Sand & $14.7 \pm 3.9$ & $26.3 \pm 5.7$ & $27.6 \pm 7.1$ & $5.2 \pm 2.3$ \\
\hline Sand/shell & $21.9 \pm 4.1$ & $52.2 \pm 3.9$ & $18.2 \pm 3.7$ & $18.3 \pm 1.5$ \\
\hline
\end{tabular}

Table 4. Ovalipes ocellatus feeding on Mexcenaria mercenaria. Expt I. Mean handling times (time elapsed in min from excavation of clam from substrate to completion of flesh consumption $\pm 1 \mathrm{SE}$ ) and mean encounter times (time engaged in active foraging between each prey handling episode $\pm 1 \mathrm{SE}$ f for crabs foraging on $5 \mathrm{clam}$ densities in sand and sand/shell. Measurements based on analysis of $3 \times 6 \mathrm{~h}$ videotape records

\begin{tabular}{|c|c|c|c|c|}
\hline Substrate & $\begin{array}{c}\text { Density } \\
\text { (clams } \mathrm{m}^{-2} \text { ) }\end{array}$ & $\begin{array}{l}\text { Mean handling } \\
\text { tıme (min) }\end{array}$ & $\begin{array}{l}\text { Mean encounter } \\
\text { time (min) }\end{array}$ & $\begin{array}{c}\text { Number of clams } \\
\text { encountered } \\
\text { and consumed }\end{array}$ \\
\hline Sand & $\begin{array}{r}24 \\
48 \\
72 \\
96 \\
120\end{array}$ & $\begin{array}{l}2.0 \pm 0.3 \\
3.3 \pm 0.6 \\
3.3 \pm 0.3 \\
2.5 \pm 1.1 \\
3.1 \pm 0.5\end{array}$ & $\begin{array}{l}6.5 \pm 4.6 \\
0.8 \pm 0.4 \\
3.8 \pm 0.5 \\
0.8 \pm 0.4 \\
2.3 \pm 0.4\end{array}$ & $\begin{array}{l}14 \\
24 \\
45 \\
13 \\
43\end{array}$ \\
\hline Sand/shell & $\begin{array}{r}24 \\
48 \\
72 \\
96 \\
120\end{array}$ & $\begin{array}{l}1.3 \pm 0.0 \\
3.2 \pm 0.6 \\
2.6 \pm 0.8 \\
3.6 \pm 1.9 \\
4.0 \pm 2.4\end{array}$ & $\begin{array}{r}45.3 \pm 0.0 \\
16.9 \pm 13.2 \\
15.2 \pm 2.8 \\
4.8 \pm 0.3 \\
8.3 \pm 3.5\end{array}$ & $\begin{array}{r}1 \\
14 \\
12 \\
35 \\
25\end{array}$ \\
\hline
\end{tabular}


(ANOVA:F $=21.7$, df $=1,20, p<0.0001)$. Crabs in the sand/shell substrate also spent more time handling non-prey items such as shell and gravel pieces than crabs foraging in sand (ANOVA:F $=12.4, \mathrm{df}=1,20$, $p=0.002$ ). For all analyses performed, differences in the proportion of time spent in either general or specific activities were not significant among prey densities. The interaction effect was also non-significant. Data are therefore presented as mean times for all prey densities to indicate general patterns (Table 3)

Handling times ranged from 1.3 to 4.0 min (Table 4 ) and were not significantly different by substrate type or prey density (Table $2 \mathrm{I}$ ). The interaction effect was also non-significant. Encounter times, however, were significantly influenced by substrate type and clam density, without significant interaction (Table 2 I). Foraging times between prey encounters were generally longer in sand/shell than in sand. A decreasing trend in encounter times with increasing prey densities was most evident in the sand/shell substrate, where the mean time between encounters ranged from 45.3 to $4.8 \mathrm{~min}$ (Table 4). In sand, clams were detected relatively rapidly at all prey densities. The less distinct relationship between encounter time and prey density in sand is therefore probably more reflective of variable crab behavior.

\section{Experiment II: Tests comparing predatory responses by Ovalipes ocellatus and Callinectes sapidus}

\section{Clam consumption}

Consumption rates for Ovalipes ocellatus and Callinectes sapidus foraging in 3 substrates at a single low clam density differed significantly by substrate type but not by crab species (Table 2 II). In addition, substrate and species interacted significantly to influence the number of clams consumed. $O$. ocellatus foraged more successfully in sand than in sand/gravel or sand/ shell (RQT:EER = 0.05), with foraging in sand/shell being least successful. Foraging by $C$. sapidus was also more successful in sand than in sand/gravel (RQT:EER $=0.05$ ). Differences in foraging success between sand and sand/shell for $C$. sapidus were barely non-significant (RQT:EER $=0.05$ ). in general, however, consumption rates were greater for both species in sand than the combination substrates (Fig. 4).

\section{Crab behavior}

Ovalipes ocellatus spent a significantly greater proportion of time buried in each of the substrates than Callinectes sapidus, while C. sapidus spent more time

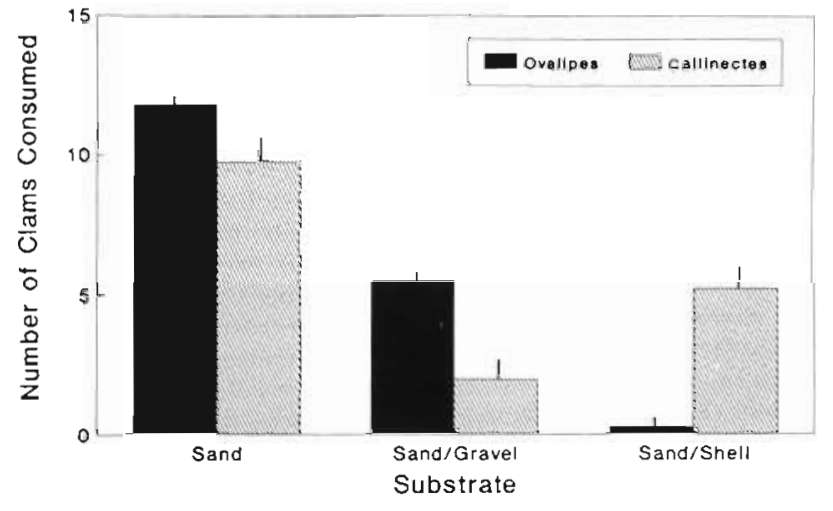

Fig. 4. Ovalipes ocellatus and Callinectes sapidus feeding on Mercenaria mercenaria. Mean number $( \pm 1 \mathrm{SE} ; \mathrm{n}=4)$ of clams consumed after $48 \mathrm{~h}$ by crabs foraging in sand, sand/ gravel and sand/shell substrates on a single low density of 24 clams $\mathrm{m}^{-2}$

in non-foraging behaviors such as walking relative to O. ocellatus (Tables 2 II and 5). Although C. sapidus appeared to spend relatively more time foraging in sand and sand/shell, with $O$. ocellatus spending correspondingly more time foraging in sand/gravel, these differences were not statistically significant (Tables 2 II and 5). Substrate did not significantly influence or interact to influence the proportion of time crabs spent in general behaviors.

Species-related patterns in time spent in specific activities are illustrated herein for the sand/shell substrate (Fig. 5). The principle between-species differences in time allocation to non-foraging behaviors was due to differences in time engaged in walking activity. In general, Callinectes sapidus spent more time walking (183.7 $\pm 56.3 \mathrm{~min})$ than Ovalipes ocellatus (45.5 \pm $19.6 \mathrm{~min}$ ) in all substrates. Analysis of specific foraging activities produced the same results as the analysis of

Table 5. Ovalipes ocellatus and Callinectes sapidus. Mean time (min $\pm 1 \mathrm{SE}$ ) crabs were engaged in general behaviors in Expt II. Times calculated from $4 \times 6$ h videotape records for each of 3 substrates

\begin{tabular}{|lrrr|}
\hline & \multicolumn{3}{c|}{$\begin{array}{c}\text { General behavior } \\
\text { Non-foraging }\end{array}$} \\
& Burial & Foraging \\
\hline Sand & & & \\
O. ocellatus & $241.6 \pm 51.4$ & $51.6 \pm 20.9$ & $10.6 \pm 4.4$ \\
C. sapidus & $21.8 \pm 10.9$ & $192.9 \pm 60.1$ & $129.0 \pm 77.0$ \\
Sand/gravel & & & \\
O. ocellatus & $191.0 \pm 52.5$ & $79.8 \pm 18.8$ & $68.2 \pm 32.6$ \\
C. sapidus & $82.8 \pm 41.4$ & $203.4 \pm 58.5$ & $11.5 \pm 3.0$ \\
Sand/shell & & & \\
O. ocellatus & $263.0 \pm 43.8$ & $41.3 \pm 25.6$ & $39.8 \pm 20.0$ \\
C. sapidus & $92.0 \pm 89.4$ & $205.1 \pm 73.3$ & $59.4 \pm 31.6$ \\
\hline
\end{tabular}




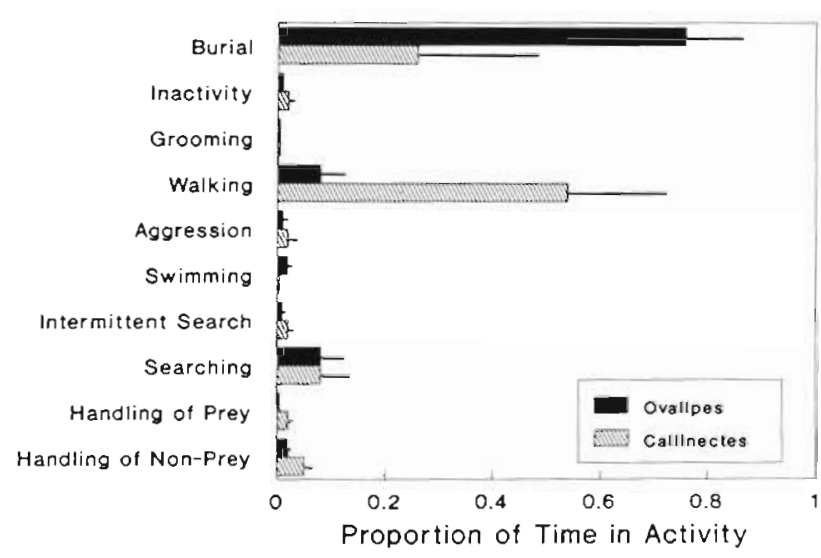

Fig. 5. Ovalipes ocellatus and Callinectes sapidus feeding on Mercenaria mercenaria prey. Mean proportion of recorded time crabs spent in specific activities in the sand/shell substrate. Data are based on analysis of $4 \times 6 \mathrm{~h}$ videotape records for each substrate

the general behavior categories. Although $C$. sapidus spent more time than $O$. ocellatus searching for and handling prey and non-prey in sand and sand/shell, and less time in sand/gravel, differences proved insignificant (ANOVA: $F=0.03$ to $3.8, d f=1,18, p=0.07$ to 0.87 ).

\section{DISCUSSION}

Substrate type and its inherent physical heterogeneity appear to influence significantly portunid $\mathrm{crab}$ foraging under laboratory conditions. Both Ovalipes ocellatus and Callinectes sapidus exhibited higher consumption rates in sand than in the more heterogeneous sand/shell and sand/gravel substrate combinations. Previous studies have shown that $C$. sapidus prefers sand, mud and sand-mud combinations to crushed oyster shell and gravel substrates, while among homogeneous substrates, $C$. sapidus has demonstrated higher consumption rates in mud than in sand (Lipcius \& Hines 1986). In addition to these studies investigating predation rates and/or preferences among homogeneous substrates, several workers have documented the importance of habitat heterogeneity (e.g. Blundon \& Kennedy 1982, Crowder \& Cooper 1982, Peterson 1982a). Few studies, however, have analyzed foraging behavior in heterogeneous substrates, despite their common occurrence in nature. In laboratory experiments mud crabs preyed more heavily on juvenile hard clams from a heterogeneous sand/gravel substrate than from sand alone, a result attributed to substrate preferences and predator avoidance by crabs (Day 1987). Results from the present study suggest that substrate type and heterogeneity may significantly influence the foraging success of por- tunid crabs. Although confounded to an extent by detailed species-specific behaviors, both $O$. ocellatus and $C$. sapidus generally exhibited greater foraging success in the least heterogeneous substrate.

Based solely on functional response analysis, it was only possible to demonstrate that crabs exhibited a Type II functional response in sand. While the greater variability of foraging success in sand/shell may have prohibited determination of functional response in that substrate, comparison of crab consumption rates revealed distinct substrate-related differences in predation success. Consumption rates for Ovalipes ocellatus were consistently higher in sand than in sand/shell across all prey densities, with the most significant difference in foraging success occurring at the lowest prey densities. Based on these observations, therefore, clams may potentially have a low density refuge from crab predation in heterogeneous substrates such as sand/shell, but not in homogeneous substrates such as sand. Lipcius \& Hines (1986), however, found such a refuge from Callinectes sapidus predation for Mya arenaria in sand. These authors were trying to explain the apparent persistence of adult $M$. arenaria (up to $80 \mathrm{~mm} \mathrm{SL}$ ) at low densities in Chesapeake Bay. Adult soft-shelled clams live 100 to $250 \mathrm{~mm}$ below the surface (Blundon \& Kennedy 1982) as opposed to the ca $30 \mathrm{~mm}$ depth which juvenile hard clams occupy. The apparently different functional response of $C$. sapidus to these 2 prey in sand highlights the species- and substrate-specific nature of functional responses. In another laboratory study, Haddon et al. (1987) found no low density refuge for the bivalve Paphies ventricosa from predation by the New Zealand paddle crab $O$. catharus. The range of experimental prey densities used in this latter study (500 to $2000 \mathrm{~m}^{-2}$ ), however, while reflecting the common occurrence of $P$. ventricosa in dense beds, was too high to provide unequivocal evidence for or against a low density prey refuge.

Integration of behavioral observations in the present study strengthens the findings based on predation rates, and enables inference of underlying mechanisms. While functional response analysis did not clearly distinguish substrate-specific differences in curve type. behavioral observations demonstrated that crabs forage less efficiently in the sand/shell substrate, particularly at low prey densities. Crabs spent more time foraging in the sand/shell substrate, but handled and consumed fewer prey. Reflecting the rapidity with which prey were encountered, the mean encounter times (time spent in intermittent search and searching activities between prey encounters) were longer in sand/shell than in sand across all prey densities. These encounter times in sand/shell also exhibited a more distinct trend with increasing prey densities, reflecting greater difficulty in prey detection at low densities in 
sand/shell. This was particularly striking at the lowest prey density where, during $18 \mathrm{~h}$ of videotaped crab behavior, only one clam was handled and consumed Additionally, the observation that more time was spent handling non-prey items in the sand/shell substrate than in sand suggests that prey detection was compromised. Both Ovalipes ocellatus and Callinectes sapidus selected and attempted to open numerous shell and/or gravel pieces during foraging periods. Prey detection and capture involves a combination of chemo- and mechanoreception (see reviews by Ache 1982, Bush \& Laverack 1982). Feeding behaviors are activated by several concentrations of chemical stimuli (Zimmer-Faust \& Case 1982, Zimmer-Faust 1989), which are detected by chemosensory organs (Derby \& Atema 1982). Stimuli are probably integrated from different receptors to activate particular behaviors (Derby \& Atema 1982), with final consumption of prey possibly determined by relative stimuli from chela and pereopod receptors (Jubb et al. 1983). The presence of shell and gravel pieces apparently confounds the integration of these diverse stimuli, creating an abundance of chemical and mechanical stimuli, and necessitating more time for prey detection. Debris may be associated with residual chemical cues and/or resemble the mechanically-detected prey shape. In a complex chemical environment, these objects would require timeconsuming manipulation for appropriate identification. Although these effects were perhaps exaggerated in the laboratory where recent predation events might have induced an artificially high concentration of chemical cues in the water, field conditions would also involve additional confounding organic cues.

Reduced foraging efficiency at low prey densities is probably also influenced by rate of prey capture. A successful capture may reinforce foraging stimuli, which may increase the efficiency with which crabs subsequently detect prey (Krebs 1973, Real 1977, 1979). In that case, foraging efficiency in heterogeneous substrates with low prey densities might be further reduced due to infrequent prey capture. Behavioral observations indicated that while a successful encounter often stimulated more searching in these trials, particularly in the same area, there were no distinct trends in the total amount of time spent in foraging behaviors in treatments of different prey densities

Other aspects of crab behavior may enhance the refuge value of particular substrates in the field. Caine (1974) and McLay \& Osborne (1985) have provided evidence that Ovalipes spp. are both morphologically and behaviorally adapted to a burrowing existence. Laboratory observations of $O$. ocellatus burrowing in several substrates (Lawton and Sponaugle unpubl.) have revealed that lady crabs encounter difficulty when burrowing in sand/shell and sand/gravel substrates. In the field, movements of $O$. ocellatus may be influenced by preferences for burial substrates. Callinectes sapidus may not be as affected by a preference for burial substrates since laboratory animals were generally more active, spending less time buried than $O$. ocellatus. Additionally, C. sapidus is not morphologically adapted for a burrowing existence. Callinectes may, however, select areas due to other factors (e.g. prey density). The ability of brachyuran crabs to move substantial distances over short periods (Hill 1978, Boulding \& Hay 1984, Hines \& Wolcott 1988) and emigrate from least preferred areas may enhance the refuge value of heterogeneous substrates in the field. This capacity for movement, however, also influences the scale at which crabs perceive patchiness. Patch dynamics should become influential with respect to how crabs detect particular areas of high or low prey density, determining the length of time spent in patches, and the efficiency with which prey are detected (Pyke et al. 1977, Kacelnik \& Krebs 1986 , Sutherland \& Anderson 1987).

Further experimental or field manipulations are necessary to examine the above factors, and the additional effects of predator numerical response (Solomon 1949, Murdoch 1973, Hassel \& May 1974) and mutual interference (Hassel 1978), the developmental response (Murdoch 1971), and both short (Cunningham \& Hughes 1984) and longterm learning (Murdoch 1973). In addition, polyphagy (Murdoch 1973, Murdoch \& Oaten 1975, Hassel 1978, Murdoch et al. 1985) and switching (Murdoch 1969, 1977, Murdoch et al. 1985, Akre \& Johnson 1979) should be of particular importance to scavengers such as crabs, and may therefore influence foraging patterns. Predation in nature also encompasses other costs (e.g. predation risk) not modelled in these laboratory experiments (Abrams 1982). Finally, the experimental conditions in this study required standardization of laboratory animals. Foraging by crabs in the field should therefore be more variable than that measured in the laboratory. In view of the multiplicity of interacting factors, verification of these laboratory results through field manipulations is critical.

While not specifically addressing these issues, several studies provide preliminary field support for the existence of low density prey refuges for Mercenaria mercenaria. The mean monthly survivorship of $M$. mercenaria juveniles planted at $100 \mathrm{~m}^{-2}$ in experimental field manipulations using azoic sand was more than 4 times greater than that of clams planted at $300 \mathrm{~m}^{-2}$ (Malinowski \& Whitlach 1983). Persistence of natural clam populations at relatively low densities $[0.9$ to $18.4 \mathrm{~m}^{-2}$, MacKenzie 1977; 11 to $81 \mathrm{~m}^{-2}$, Greene 1978; $16 \mathrm{~m}^{-2}$, Buckner 1979 (see review in Walker 1987); 
$8 \mathrm{~m}^{-2}$, J. Kassner pers. comm.] in areas around Long Island also provides corroborative evidence that a low density refuge exists for natural populations of hard clams. Additional support for low density bivalve refuges exists in a field study by Boulding \& Hay (1984) where high density plots of littleneck clams (Protothaca staminea) in pebble/sand substrates suffered greater predation losses to crabs than did low density plots. Peterson (1982b) also showed a trend, although statistically non-significant, of higher predation by Cancer sp. at higher $P$. staminea densities.

The present laboratory analysis has provided a preliminary model of portunid crab foraging efficiency on Mercenaria mercenaria in different substrates, and has suggested potential considerations, related to substrate heterogeneity, for defining prey refuges in the field. It may prove feasible to manipulate field substrates and planting densities to reduce the effects of portunid crab predation on hatchery-raised juvenile hard clams. In addition, the comparative aspect of this work has demonstrated that the foraging behavior of 2 common portunid crabs is similar, and conclusions based on a single crab species may in some cases be generally applicable to other portunids. The explicit integration of behavioral observations with an analysis of consumption rates has revealed the importance of habitat heterogeneity in influencing foraging behavior. Where functional response analysis falls short of explaining a particular predation interaction, behavioral observations can provide essential information on underlying mechanisms.

Acknowledgements. We thank R. K. Cowen, R. E. Cerrato and R. Lipcius for valuable discussions during this work; $H$ Ruben and B. Fouke for laboratory and field assistance; and 2 anonymous referees for critical comments on an earlier draft. This work was supported through New York State Sea Grant Institute by NOAA, Office of Sea Grant, US Department of Commerce, under Grant \#NA86AA-D-SG045, Project \#R/ F42. The US Government is authorized to produce and distribute reprints for governmental purposes.

\section{LITERATURE CITED}

Abrams, P. A. (1982). Functional responses of optimal foragers. Am. Nat. 120:382-390

Ache, B. W (1982). Chemoreception and thermoreception. In: Atwood, H. L., Sandeman, D. C. (eds.) The biology of Crustacea. Academic Press, New York, p. 369-398

Akre, B. G., Johnson, D. M. (1979). Swltching and sigmoid functional response curves by damselfly nalads with alternative prey available. J. Anim. Ecol. 48: 703-720

Arnold, W S. (1984). The effects of prey size, predator size, and sediment composition on the rate of predation of the blue crab. Callinectes sapidus Rathbun, on the hard clam. Mercenaria mercenaria (Linné). J. exp. mar Biol. Ecol. 1984: $207-219$

Blundon, J., Kennedy, V. S. (1982). Refuges for infaunal bival- ves from blue crab, Callinectes sapidus (Rathbun), predation in Chesapeake Bay. J. exp. mar. Biol. Ecol 65: 67-81

Boulding, E. G., Hay, T K. (1984). Crab response to prey density can result in density-dependent mortality of clams. Can. J. Fish. aquat. Sci. 41. 521-525

Buckner, S. C. (1979). Shellfish management in the Town of Islip. Proc. Symp. Mariculture in New York State. New York Sea Grant Inst. and Cornell Univ., New York

Buckner, S. C. (1983). A case study on management of the hard clam resource in. Great South Bay. In: Buckner, S. C. (ed.) Proceedings of a management perspective on the hard clam resource in the Great South Bay. Town of Islip, New York

Bush, B. M. H., Laverack, M. S. (1982). Mechanoreception. In Atwood, H. L., Sandeman, D. C. (eds.) The biology of Crustacea. Academic Press, New York, p. 399-458

Caine, E. A. (1974). Feeding of Ovalipes guadulpensis (Saussurel (Decapoda. Brachyura: Portunidae), and morphological adaptations to a burrowing existence. Biol. Bull. mar biol Lab., Woods Hole 147: 550-559

Castagna, M., Kraeuter, J. N. (1977). Mercenaria culture using stone aggregate for predator protection. Proc. natn. Shellfish. Ass. 67: 1-6

Cronin, T. W. (1986). Photoreception in marine invertebrates. Am. Zool. 26: 403-415

Crowder, L. B., Cooper, W E. (1982). Habitat structural complexity and the interaction between bluegills and their prey. Ecology 63: 1802-1813

Cunningham, P. N. Hughes, R. N. (1984). Learning of predatory skills by shorecrabs Carcinus maenas feeding on muscles and dogwhelks. Mar Ecol. Prog. Ser. 16: 21-26

Day, E. A. (1987). Substrate type and predatory risk: effects on mud crab predation of juvenile hard clams. MS thesis. State L.niversity of New York, Stony Brook

Day, E. A.. Lawton, P. (1989). Mud crab (Crustacea: Brachyura: Xanthidae) substrate preference and activity. J. Shellfish Res. 7: 421-426

Day, R. W., Quinn, G. P. (1989). Comparisons of treatments after an analysis of variance in ecology. Ecol. Monogr 59: 433-463

Dayton, P. K. (1984). Processes structuring some marine communities: are they general? In: Strong, Jr., D. R., Simberloff, D., Abele, L. G., Thistle, A. B., (eds.) Ecological communities: conceptual issues and the evidence. Princeton Univ. Press, Princeton, p. 181-197

Derby, C. D., Atema, J. (1982). The function of chemo- and mechanoreceptors in lobster (Homarus americanus) feeding behaviour. J. exp. Biol. 98: 317-327

Dunbrack, R. L., Giguere, L. A. (1987). Adaptive responses to accelerating costs of movement: a bioenergetic basis for the Type-III functional response. Am. Nat. 130: 147-160

Eggleston, D. B. (1990). Behavioural mechanıms underlyıng variable functional responses of blue crabs, Callinectes sapidus feeding on juvenile oysters, Crassostrea virginica. J. Anim. Ecol. 59: 615-630

Einot, F. Gabriel, K. R. (1975). A study of the powers of several methods of multiple comparisons. J. Am. Stats. Ass. 70 : 574-583

Flagg, P. J., Malouf, R. E. (1983). Experimental plantıngs of juveniles of the hard clam Mercenaria mercenaria (Linné) in the waters of Long Island, New York. J. Shellfish Res. 3: $19-27$

Greene, C. H., Laudry, M. R., Monger, B. C. (1986). Foraging behavior and prey selection in the entangling predator Pleurobrachsa bachei. Ecology 67. 1493-1501

Greene, G. T (1978). Population structure, growth and mortality of hard clams at selected locations in Great South Bay. 
New York. MS thesis, State University of New York, Stony Brook

Haddon, M., Wear, R. G., Packer, H. A. (1987). Depth and density of burial by the bivalve Paphies ventricosa as refuges from predation by the crab Ovalipes catharus. Mar Biol. 94: 25-30

Hassel, M. P. (1978). Dynamics of arthropod predator-prey systems. Princeton Univ. Press, Princeton

Hassel, M. P., Lawton, J. H., Beddington, J. R. (1977). Sigmoid functional responses by invertebrate predators and parasitoids. J. Anim. Ecol. 46: 249-262

Hassel, M. P., May, R. M. (1974). Aggregation of predators and insect parasites and its effect on stability. J. Anim. Ecol. 43: $567-594$

Hill, B. J. (1978). Activity, track and speed of movement of the crab Scylla serrata in an estuary. Mar. Biol. 47: 135-141

Hines, A. H., Wolcott, T G. (1988). Blue crab movement and feeding measured by ultrasonic telemetry. Nat. Blue Crab Conf. Abst., Virginia Beach

Holling, C. S. (1959). Some characteristics of simple types of predation and parasitism. Can. Ent. 91. 385-398

Holling, C. S. (1965). The functional response of predators to prey density and its role in mimicry and population regulation. Mem. ent. Soc. Can. 45: 3-60

Jubb, C. A., Hughes, R. N., Ap Rheinallt, T (1983). Behavioural mechanisms of size-selection by crabs, Carcinus maenas (L.) feeding on mussels, Mytilus edulis L. J. exp. mar Biol. Ecol. 66: 81-87

Kacelnik, A. Krebs, J. R. (1986). Learning to exploit patchily distributed food. In: Sibly, R. M., Smith, R. H (eds.) Behavioural ecology: ecological consequences of adaptive behaviour. Blackwell Scientific Publ., Oxford, p. 189-205

Kraeuter, J. N., Castagna, M. \{1980\}. Effects of large predators on the field culture of the hard clam Mercenaria mercenaria. Fish. Bull. U.S. 78: 538-541

Krebs, J. R. (1973). Behavioral aspects of predation. In. Bateson, P. P. G., Klopfer, P. H. (eds.) Perspectives in ethology. Plenum Press, New York, p. 73-111

Lipcius, R. N., Hines, A. H. (1986). Variable functional responses of a marine predator in dissimilar homogeneous microhabitats. Ecology 67: 1361-1371

Mackenzie, C. L. Jr (1977). Predation on the hard clam $M$ mercenaria populations. Trans. Am. Fish. Soc. 106 $530-537$

Malinowski, S. M., Whitlach, R. B. (1983). Natural survivorship of young hard clams, Mercenaria mercenaria (Linné) in eastern Long Island Sound. Natn. Shellfish Ass. Annual Mtg. Abst., Hilton Head Island, J. Shellfish Res. 4: 94

McHugh, J. L. (1983). An overview of the hard clam resource. In: Buckner, S. C. (ed.) Proceedings of a management perspective on the hard clam resource in Great South Bay. Town of Islip, p. 3-9

McLay, C. L., Osborne, T. A. (1985). Burrowing behavior of the paddle crab Ovalipes catharus (White 1843) (Brachyura: Portunidae). N.Z. J. mar. Freshwat. Res. 19: 125-130

Menzel, R. W., Cake, E. W., Haines, M. L., Martin, R. E., Olsen, L. A. (1976). Clam mariculture in northwest Florida: field study on predation. Proc. natn. Shellfish. Ass. 65: $59-62$

Murdoch, W. W (1969). Switching in general predators:

This article was presented by Professor C. H. Peterson, Morehead City, North Carolina, USA experiments on predator specificity and stability of prey populations. Ecol. Monogr. 39: 335-354

Murdoch, W. W. (1971). The developmental response of predators to changes in prey density. Ecology 53: 132-137

Murdoch, W W. (1973). The functional response of predators J. appl. Ecol. 10: 335-342

Murdoch, W. W. (1977). Stabilizing effects of spatial heterogeneity in predator-prey systems. Theo. Popul. Biol. 11: $252-273$

Murdoch, W. W., Chesson, J., Chesson, P. L. (1985). Biological control in theory and practice. Am. Nat. 125: 344-366

Murdoch, W. W., Oaten, A. (1975). Predation and population stability. Adv. ecol. Res. 9: 1-131

Paine, R. T (1980). Food webs: linkage, interaction strength and community infrastructure. J. Anim. Ecol. 49: 667-685

Peterson, C. H. (1982a). Clam predation by whelks (Busycon spp.): experimental tests of the importance of prey size, prey density, and seagrass cover. Mar. Biol. 66: 159-170

Peterson, C. H. (1982b). The importance of predation and intra- and interspecific competition in the population biology of two infaunal suspension-feeding bivalves, Protothaca staminea and Chione undatella. Ecol. Monogr. 52: $437-475$

Pyke, G. H., Pulliam, H. R., Charnov, E. L. (1977). Optimal foraging: a selective review of theory and tests. Qt. Rev. Biol. 52: 137-154

Real, L. (1977). The kinetics of functional response. Am. Nat. 111: $289-300$

Real, L. (1979). Ecological determinants of functional response. Ecology 60: 481-485

Sih, A., Crowley, P., McPeek, M., Petranka, J., Strohmeier, K. (1985). Predation, competition, and prey communities: a review of field experiments. A. Rev. Ecol Syst. 16: 269-311

Solomon, M. E. (1949). The natural control of animal populations. J. Anim. Ecol. 18: 1-35

Sutherland, W. J., Anderson, C. W. (1987). Six ways in which a foraging predator may cncounter options with different variances. Biol. J. Linn. Soc. 30: 99-114

Trexler, J. C., McCulloch, C. E., Travis, J. (1988). How can the functional response best be determined? Oecologia 76 : 206-214

Valiela, I. (1984). Marine ecological processes. Springer-Verlag, New York

Walker, R. L. (1987). Hard clam Mercenaria mercenaria (Linné) populations of coastal Georgia. Georgia Marine Science Center Tech. Rep. 87-1. Georgia Sea Grant College Program

Whetstone, J. M., Eversole, A. G. (1978). Effects of size and temperature on mud crab, Panopeus herbstii, predation on hard clams, Mercenaria mercenaria. Estuaries 4: 153-156

Wilkinson, L. (1987). SYSTAT: the system for statistics. SYSTAT, Inc. Evanston

Zar, J. H. (1984). Biostatistical analysis. Prentice-Hall, Inc., New Jersey

Zimmer-Faust, R. K. (1989). The relationship between chemoreception and foraging behavior in crustaceans. Limnol. Oceanogr. 34: 1367-1374

Zimmer-Faust, R. K., Case, J. F. (1982). Organization of food search in the kelp crab, Pugettia producta (Randall). J. exp. mar. Biol. Ecol. 57: 237-255

Manuscript first received: October 13,1989

Revised version accepted: July 18, 1990 